\title{
IMPLEMENTASI PROGRAM TAHFIDZ DI MADRASAH TSANAWIYAH AL-MUHSIN II DALAM MENUMBUHKAN MINAT TILAWATIL QURAN
}

\author{
Fatah Saiful Anwar \\ Universitas Islam Negeri Sunan Kalijaga Yogyakarta \\ fatahsaifulanwar@gmail.com \\ Erni Munastiwi \\ Universitas Islam Negeri Sunan Kalijaga Yogyakarta \\ erni.munastiwi@uin-suka.ac.id
}

\begin{abstract}
ABSTRAK
Pengajaran Al-Quran di sekolah sangat perlu dengan kegiatan atau program khusus agar dapat memenuhi tuntutan pendidikan Islam di madrasah formal. Penelitian ini berusaha untuk meneliti bagaimana implementasi program Tahfidz Al-Quran di madrasah formal dan imbasnya terhadap minat peserta didik dalam kegiatan Tilawatil Quran di sekolah, mengacu pada model-model pengajaran AlQuran di sekolah meliputi metode, strategi, maupun penyampainnya. Jenis penelitian ini termasuk kualitatif dan sebagai model pengembangan konsep, teknik pengumpulan datanya meliputi observasi, wawancara, dan dokumentasi. Analisis data menggunakan trianggulasi dan reduksi data, dan kesimpulan. Hasilnya menunjukan bahwa upaya implementasi program tahfidz di Madrasah Tsanawiyah Al-Muhsin II akan memiliki daya tarik terhadap minat anak didik dalam Tilawah Al-Quran apabila dikemas dengan beberapa hal pendukung meliputi kompetensi guru yang baik, dukungan fisik maupun nonfisik, metode ajar yang menarik, elaborasi pengajaran yang baik, dan juga buku panduan tahfidz yang menjadi rujukan harus jelas. Dengan hal inilah akan dapat menarik minat anak didik dalam kegiatan Tilawatil Quran.
\end{abstract}

Kata Kunci: program tahfidz, minat, tilawatil quran

\section{ABSTRACT}

Teaching the Quran in schools is necessary with special activities or programs in order to meet the demands of Islamic education in formal madrasah. This research seeks to examine how the implementation of tahfidz al-Quran program in madrasah formal and its impact on the interest of students in the activities of Tilawatil Quran in schools, referring to the models of teaching the Quran in schools including methods, strategies, and presenters. This type of research includes qualitative and as a model of concept development, its data collection techniques include observation, interviews, and documentation. Data analysis using trianggulation and data reduction, and conclusions. The results show that the implementation of tahfidz program in Madrasah Tsanawiyah Al-Muhsin II will have an appeal to the interest of students in the Tilawah Al-Quran when packed 
with several supporting things including good teacher competence, physical and nonphysical support, interesting teaching methods, good teaching elaboration, and also tahfidz manual that becomes a reference must be clear. This will be able to attract students in the activities of Tilawatil Quran.

Key Words: tahfidz program, interests, tilawatil quran

\section{PENDAHULUAN}

Al-Quran sebagai mukjizat Nabi Muhammad SAW merupakan kalam illahi adalah spirit umat Islam tersendiri sehingga mendorong agar senantiasa melestarikan Al-Quran dari kepalsuan. Adapun salah satu cara yang ditempuh adalah dengan cara menghafalkannya. Di pesantren, program semacam ini biasa dikenal dengan istilah tahfidzul Quran, sedangkan dewasa ini program sejenis juga telah banyak diterapkan di sekolah-sekolah maupun madrasahmadrasah formal.

Program semacam ini tentunya akan senantiasa mengalami perbaikan, perbaruan, dan evaluasi. Terutama dalam hal metode pembelajarannya yang harus sesuai dengan kebutuhan peserta didiknya agar pelaksanaannya semakin efektif dan efesien untuk mengembangkan program tahfidz (Rohmatillah \& Shaleh, 2018).

Program Tahfidz Al-Quran disebuah sekolah sendiri memiliki dampak tersendiri terhadap pemenuhan pembelajaran di tempat yang lain, yakni dapat menyokong kebutuhan dalam mata pelajaran agama yang ada di sekolah selain itu juga program ini juga diharapkan melahirkan pribadi yang mahir dalam hal baca tulis Al-Quran, tilawatil Quran, maupun penghafal Quran handal.

Semakin berkembangnya zaman terdapat problem tersendiri di mana minat anak dalam hal Al-Quran dan agama akan terancam, sebenarnya minat orang tua untuk memasukan anak di pesantren secara khusus pada umumnya dimiliki oleh sebagian besar orang tua, namun hal tersebut kadang terhalang oleh rasa tidak tega melepaskan anaknya jauh dari sisi orang tua (Sitna et al., 2019). Dalam kondisi seperti inilah sekolah atau madrasah formal sebagai pihak kedua penyelenggaraan pendidikan agama paling tidak menyediakan program serupa sebagai jalan keluar atau alternatif peserta didik dan orang tua dalam membimbing anaknya dalam bidang agama (Supriatna, 2018).

Berkenaan dengan ini maka peran mentor dalam program tahfidz tentu sangat penting mengingat sebagai pemilik strategis dalam mengambangkan potensi peserta didik. Maka anak apabila akan dibentuk menjadi kreatif maka guru pun harus memiliki kreatifitas. Diharapkan guru mampu memberikan pendekatan dan variasi selama program pembelajaran. Guru atau mentor dalam menyampaikan proses pembelajaran harus mempunyai strategi yang dibutuhkan untuk dikembangkan dalam diri anak didik untuk mengekspresikan ide, gagasan, pemikiran, dan pendapat yang dituangkan ke dalam suatu karya. Maka dalam hal ini harus meliputi kegiatan yang bisa menjadi stimulan untuk potensi, minat, bakat yang diharapkan (Taher \& Munastiwi, 2019).

Metode tilawati merupakan metode dasar dan mudah dipahami yang digunakan dalam tahsin Al-Quran (Khoiruddin \& Kustiani, 2020). Berkaitan dengan hal tersebut peneliti tertarik untuk meneliti tentang implementasi program tahfidz dan andilnya dalam mengembangkan minat peserta didik dalam hal 
Tilawatil Quran karena jika melihat kurikulum sendiri Tilawatil Quran adalah sesuatu yang menjadi bagian dari pendidikan Islam di sekolah. Seperti dalam pembelajaran Al-Quran Hadist peserta didik dituntut untuk dapat melakukan kegiatan seputar itu diantaranya adalah membaca Al-Quran, menghafalkan, dan memahaminya. Penelitian ini berjudul Implementasi Program Tahfidz Dalam Menumbuhkan Minat Tilawatil Quran dengan tujuan untuk mencari deskripsi rill terkait dampak program Tahfidz di Sekolah terkait terhadap minat peserta didik dalam kegiatan Tilawatil Quran.

\section{METODE}

Metode penelitian ini adalah kualitatif, yakni metode yang berlandaskan pada pola pemikiran dunia konstruktivis yang mana memandang secara konstruktif dalam memandang realitas sesuai dengan kondisi ruang dan waktu yang ada. Tipe konstruktivis akan memandang suatu masalah dengan cara menafsirkan fenomena-fenomena yang ditafsirkan oleh orang lain tentang dunia ini. Maka peneliti tidak berangkat dari teori namun mengembangkan teori secara induktif. Adapun teknik mengumpulkan data melalui observasi, dokumentasi, dan wawancara. Analisis data sendiri dilakukan secara induktif. Memandang masalah secara holistik dan menyeluruh. Hasil merupakan refleksi dan generalisasi atas interpretasi data (Creswell, 2014, p. 256). Penentuan sumber data dalam penelitian ini adalah guru dan peserta didik. Dan berdasarkan data wawancara, observasi, dan dokumentasi, akan di analisis menggunakan teknik analisis triangulate (mentriangulasi), penarikan kesimpulan dan verifikasi. Sedangkan untuk menguji keabsahan data menggunakan member checking dan klarifikasi bias data (Creswell, 2014, pp. 269-270).

\section{HASIL DAN PEMBAHASAN \\ Program Tahfidz Al-Quran}

Sebelum masuk membahas apa itu program Tahfidz Al-Quran maka perlu terlebih dahulu meninjau apa itu Tahfidz Al-Quran. Tahfidz Al-Quran adalah terdiri dari suku kata Bahasa Arab yaitu Tahfidz dan Al-Quran. Kata tahfidz adalah menghafal sedangkan pelakunya adalah hadifz, oleh Quraisy Syihab ini dimaknai sebagai memelihara dan mengawasi, dan dari sinilah muncul makna menghafal. Karena upaya menghafal sebagai wujud memelihara dengan ingatannya, selain itu tahfidz juga memiliki makna tidak lengah karena hal ini mengarah pada keterpeliharaan, dan menjaga karena penjagaan adalah sebagian dari pemeliharaan(Shihab, 2006, p. 58).

Dalam kamus Besar Bahasa Indonesia kata hafal adalah masuk dalam ingatan (tentang pelajaran) dan dapat mengucapkan diluar kepala (tanpa melihat) kata menghafal adalah bentuk kata kerja yang berarti berusaha keras untuk memasukan ke dalam ingatan sehingga menetap sebagai hafalan yang bisa diingat setiap membutuhkannya.

Sementara Al-Quran dalam Tim Penerjemah Kemenag adalah Al-Qur'an berasal dari bahasa Arab qoro'a-yaqro'u-qur'anan berarti membaca. Kata AlQuran sendiri berupa masdar atau maf'ul mutlak dari kata tersebut bermakna sebagai objek bacaan. Dikutip dari Manna' Khalil Al-Qatthan lafadz Al-Quran berasal dari kata qara'a yang artinya menghimpun dan mengumpulkan maka Qiro'ah adalah menghimpun huruf-huruf dan kata-kata untuk dijadikan ucapan 
yang tersusun rapi sehingga Al-Quran sebagai bentuk mashdar atau maf'ul muthlak diartikan sebagai objek bacaan. (Tim Penerjemah Kemenag, 1971, p. 15).

Tujuan dari ini adalah sebagai wujud pengajaran yang mutlak adanya sebagi wasilah untuk menuju tujuan utama yakni, pengajaran Al-Quran diselengarakan menurut Tim Penyusun kurikulum Nasional balai LITBANG LPTQ Nasional Yogyakarta adalah untuk menyiapkan terbentuknya generasi Qur'ani, yaitu generasi yang memiliki komitmen terhadap Al-Quran sebagai sumber perilaku, pijakan hidup, dan rujukan segala urusan. Sedangkan berdasarkan (PP) No. 55 Tahun 2007 tentang Pendidikan Al-Quran dan Pendidikan Agama dalam Pasal 24 Ayat 2 adalah usaha untuk meningkatkan kemampuan peserta didik membaca, menulis, memahami dan mengamalkan kandugan AI-Quran (Muhlisin, 2017).

Apabila memahami beberapa makna Tahfidz dan makna Al-Quran sedangkan makna program adalah suatu rancangan mengenai asas serta usaha yang akan dijalankan (KBBI) maka program Tahfidz adalah suatu kegiatan yang dapat mengkondisikan secara efektif dan efesien proses kegiatan peserta didik dalam belajar membaca, memahami, menghafalkan Al-Quran.

\section{Metode Pengajaran Al-Quran Secara Talaqqi}

Metode pengajaran Talaqqi adalah metode mengajar yang diajarkan Nabi Muhammad SAW kepada para Sahabat Nabi, kemudian oleh mereka dilanjutkan sampai sekarang. Metode ini dianggap sebagai metode yang menyeluruh dalam penyampaian materi Al-Quran dan paling mudah diikuti oleh siapa saja. Hal ini apabila lebih jauh lagi sebenarnya juga terjadi antara malaikat Jibril AS ketika menyampaikan wahyu kepada Rosululloh pun dilakukan demikian. Inilah hal yang menjadi legislasi pengajaran yang shohih hingga sekarang. Hal ini dilakukan semata adalah untuk menjaga orisinilitas Al-Quran.

Dalam pembelajaran Al-Quran terdapat banyak metode dan cara yang bisa digunakan di antaranya adalah pertama metode Sima'i adalah metode di mana peserta didik mendengarkan bacaan guru kemudian mengingatnya atau merekamnya dengan alat Recorder dan rekaman tersebut menjadi landasan peserta didik untuk membaca Al-Quran bahkan menghafalkannya. Kedua adalah metode Wahdah metode ini adalah berupa pengulangan-pengulangan dalam menghafalkan Al-Quran dengan cara dibaca terlebih dahulu sebanyak 10 kali, kemudian kalau sudah dilanjutkan ayat berikutnya sampai satu halaman terhafal selanjutnya menghafalkan urutan-urutannya. Ketiga adalah metode Kitabah metode ini adalah berupa kegiatan peserta didik menuliskan ayat-ayat suci AlQuran untuk kemudian dibaca dan dihafalkannya, sebagai salah satu cara agar peserta didik lebih bisa mengingat hafalannya. Keempat adalah metode Jama' adalah metode yang dilakukan secara bersama-sama yang dipandu oleh seorang instruktur atau guru, dengan bacaan yang baik dan benar. Kelima adalah metode Talqin adalah dengan cara menuntun peserta didik dalam membaca AlQuran yang baik yang benar. Keenam adalah metode gabungan yaitu gabungan antara metode Sima'i dan Kitabah atau Kitabah dan Wahdah. Atau penggabungan lainnya.

Perlu diketahui bahwa dalam agama Islam pembelajaran agama Islam harus dilakukan secara talaqqi, hal tersebut wajib hukumnya sebagai bukti 
riwayat pengajaran yang bersambung secara isnadiyah (memiliki sanad ajar sampai Rosulullah SAW) oleh karena itu selamanya pelajaran agama tidak akan terwakili sepenuhnya oleh internet. Dalam Islam istilah pengajaran talaqqi adalah suatu keniscayaan. Talaqqi adalah pengajaran yang dilakukan secara tatap muka antara peserta didik dan guru yang memiliki kompetensi ilmu yang mumpuni dari segi keilmuan, tsiqah, amanah, memiliki sanad keilmuan yang muttashil (nyambung) sampai pada Rosulullah SAW. Melalui jalur ulama-ulama setelah Nabi Muhammad SAW karena ulama adalah pewaris para nabi.

Terlebih dalam pengajaran Al-Quran Talaqqi adalah suatu keniscayaan karena ketika guru menyampaikan bacaan Al-Quran haruslah melalui musyafahhah (peserta didik melihat gerak bibir gurunya secara tepat). Hal ini dilakukan secara berhadapan antara guru dan peserta didik dalam posisi duduk dengan tenang dan nyaman, kemudian guru akan membimbing peserta didik untuk mengulanginya beberapa kali sampai benar dalam melafalkannya. Cara ini dianggap sebagai cara yang paling efektif dalam pengajaran AI-Quran (Putra, 2016).

\section{Tahsinul Quran}

Sebelum menghafalkan Al-Quran sudah wajib hukumnya untuk menguasai bacaan yang benar terlebih dahulu maka perlu melakukan pengajaran Tahsinul Qiro'ah. Metode Tahsin adalah cara untuk suatu kegiatan yang sudah tersusun rapi untuk memperbaiki atau membaguskan bacaan AlQuran sesuai dengan perintah Allah dalam Al-Quran.

Di lain sisi sebenarnya tahsinul Qiro'ah sendiri amat perlu juga dilakukan di kalangan umat muslim secara keseluruhan mengingat masih banyaknya muslim atau muslimah yang masih kurang bisa dalam membaca Al-Quran sedangkan Al-Quran sendiri merupakan bacaan harian umat muslim sebagai usaha agar mendapatkan syafaat kelak di hari kiamat (Prasetiawati, 2019).

\section{Metode Menghafal Al-Quran}

Siapa saja sebenarnya bisa dan memiliki potensi untuk bisa menghafal, namun dalam hal Tahfidz Al-Quran tentu tidak bisa disamakan seperti halnya menghafal hal selain Al-quran. Maka disinilah dibutuhkan metode atau cara khusus dalam melaksanakannya. Metode dan cara sangatlah penting untuk mencapai keberhasilan menghafal. Suatu program akan mencapai tujuan yang diinginkan sesuai ketepatan dalam memilih metode yang dapat mencapainya. Di antara metode dalam program Tahfidz adalah metode wahdah, metode kitabah, metode sima'l, metode gabungan, metode muroja'ah, metode al-Qashimi, metode jamak dan metode Takrir (pengulangan) (Rohmatillah \& Shaleh, 2018).

Sedangkan dalam pengajaran Al-Quran bahwa kaidah pengajaran AlQuran sendiri harus berdasarken empat asas yakni Tahqiq (bacaan yang tenang dan tidak tergesa-gesa yang bertujuan untuk mengajarkan dan menghayatkan Al-Quran pada peserta didik, Tartil (pelan dan sesuai kaidah baca Al-Quran), AtTadwir (bacaan yang sederhana tidak terlalu cepat dan dengan tajwid), Al-Hadar (bacaan cepat namun tetap memperhatikan bacaan tajwidnya).

Sedangkan dari segi metode pengajarannya menurut Ahmad mengemukakan dalam pelaksanaan dan pengelolaan kaidah di atas dilakukan menggunakan teknik atau strategi guru pengampu dalam menyampaikan 
materinya secara kreatif seperti metode menghafal, mengartikan, menuliskan AlQuran, adalah strategi yang lazim digunakan dalam pembelajaran Al-Quran (Che Noh \& Ahmad, 2009).

\section{Peran Guru Tahfidz dalam mengembangkan minat Peserta didik terhadap Tilawah Al-Quran}

Guru memiliki posisi sentral dalam pengajaran Al-Quran mengingat AlQuran tidak bisa dipelajari secara otodidak (tanpa guru) dalam meningkatkan minat peserta didik dalam tilawah Al-Quran. Guru dalam proses pengajaran sangatlah dibutuhkan dan sangat menentukan keberhasilan anak didiknya. Anak didik tidak bisa lepas dari kiprah guru, oleh karena itu mutu pendidikan sangatlah bergantung pada mutu guru atau pengajarnya. Para ahli pendidikan barat seperti Pullias, Young, Manan, Yelon, dan Weinstein telah melakukan penelitian tentang peran guru setidaknya terdapat 19 peran yaitu guru sebagai pendidik, pengajar, pembimbing, pelatih, penasehat, inovator, model dan teladan, pribadi yang baik, sebagi peneliti, pendorong kreativitas, pembangkit pandangan, pekerja rutin, penunjuk jalan, pembawa cerita, aktor utama, emansipator, evaluator, pengawet warisan budaya luhur, dan sebagai kulminator (Putra, 2016, pp. 34-38).

Guru merupakan komponen penting ketika mengadakan proses belajar mengajar di sekolah. Walaupun demikian guru adalah sosok yang ditiru, digugu, dan diteladani baik dari segi pengetahuan maupun kepribadiannya (Taher \& Munastiwi, 2019). Di dalam proses pengajaran hendaknya guru melibbatkan aktif peserta didiknya dalam proses pengajaran (Hasyimi, 1994). Selain itu guru juga telah membuat rancangan pembelajaran sesuai dengan kondisi kelasnya. Dalam pembelajaran AI-Quran ia memiliki ciri tersendiri yang memiliki kesesuaian dengan pendidikan Islam, pembelajaran AI-Quran membutuhkan ketrampilan lisan, kelancaran bacaan, kemahiran dalam membaca dengan fasih, menguasai ilmu Tajwid, Tadwir dan Tartil.

Dalam pembelajaran Al-Quran agar memiliki kesan tersendiri bagi peserta didik maka guru harus memiliki ketrampilan tersendiri terkait strategi pengajaran yang digunakan, kaidah dan teknik selama mengajar Al-Quran sangat menentukan bagaimana pengajaran akan memberi kesan pada peserta didik selama proses belajar (Che Noh \& Ahmad, 2009).

\section{Hasil Penelitian Program Tahfidzul Quran Di MTs Al-Muhsin II Bantul}

Madrasah Tsanawiyah Al-Muhsin II Kasihan beralamat di Dusun Kalirandu, Desa Bangunjiwo Kecamatan Kasihan, Kabupaten Bantul, Proovinsi Daerah Istimewa Yogyakarta dengan kode pos 55181. Sekolah ini berdiri pada tahun 2016 dengan nomor SK. KW.12.2/5/PP.00/19/2016 dengan Akreditasi B. Madrasah ini berdiri di bawah naungan Yayasan Pondok Pesantren Aji Mahasiswa Al-Muhsin Krapyak. Madrasah ini jika dilihat dari segi geografis terletak di sebuah pedesaan, madrasah ini didirikan atas dasar dakwah Islamiyah melalui jalur pendidikan. Madrasah ini mencoba untuk menggabungkan antara sistem pondok pesantren nonformal dan sistem sekolah formal. Terdapat beberapa mata pelajaran lokal yang dinilai menjadi ciri khas madrasah meliputi mata pelajaran kepesantrenan dan juga Tahfidz AI-Quran.

Di Madrasah Tsanawiyah Al-Muhsin II telah memberlakukan program Tahfidz Quran sesuai yang telah di atur oleh PP No. 55 Tahun 2007 tentang Pendidikan Al-Quran dan Pendidikan Agama dalam Pasal 24 Ayat 2. Dan 
diresmikan sebagai mata pelajaran lokal yang diwajibkan di madrasah bagi semua peserta didik.

Kegiatan Tahfidzul Quran adalah setiap kegiatan literasi yang dilakukan peserta didik dan guru berkaitan dengan AI-Quran, meliputi kegiatan belajar membaca Al-Quran, menuliskan AI-Quran, menghafalkan AI-Quran, melagukan bacaan Al-Quran, dan mengartikan Al-Quran. Dari segi penamaan memang menggunakan istilah Tahfidz yang berarti menghafal, karena memang tujuan pokok darinya adalah menghafal Al-Quran. Namun di madrasah sendiri belum semua mampu menerapkan hal tersebut dikarenakan berbeda-bedanya kemampuan peserta didik dalam menguasai baca tulis Al-Quran (BTQ).

Sebelum seorang peserta didik menghafalkan Al-Quran secara mutqin (dihafalkan untuk selamanya) maka ada satu hal penting yang dipenuhi yaitu kemampuan membaca AI-Quran yang sudah baik dari segi tartilul Quran, tajwid, makhorijul huruf, maupun kaidah lainnya. Namun salah satu keprihatinan saat ini adalah terdapat banyak sekali kegiatan menghafal Al-Quran, namun belum memenuhi sarat sehingga secara berantai hal ini dibahayakan akan merusak orisinilitas Al-Quran dari segi bacaan. Secara umum ada empat kegiatan khusus dalam pengajaran Tahfidz Al-Quran di MTs Al-Muhsin II yaitu belajar membaca Al-Quran, belajar menuliskan AI-Quran, tartil Al-Quran, Makhorijul huruf, dan tajwid Al-Quran.

Sebagian besar sekolah/madrasah yang menerapkan program tahfidz (menghafalkan) adalah sebagai peminatan bukan sebagai kewajiban. Sedangkan kemampuan membaca Al-Quran adalah keniscayaan yang harus dimiliki peserta didik, sehingga mau tidak mau semua peserta didik harus mengikuti kelas Tahfidzul Quran tersebut. Maka dalam suatu program akan dibagi menjadi dua kelompok, yakni satu kelompok sebagai kelompok penghafal Al-Quran (bagi yang sudah bisa membaca Al-Quran dengan baik dan benar), dan kelompok dua adalah kelompok martikulasi dari mereka yang masih terkendala baca tulis Al-Quran (BTQ). Apabila melihat kenyataan lapangan di MTs AlMuhsin II adalah termasuk madrasah yang memberlakukan program Tahfidz Quran sebagai mata pelajaran wajib yang harus diikuti oleh semua peserta didik, dan dijadikan standar lokal dalam kenaikan kelas maupun kelulusan peserta didik.

Program Tahfidz AI-Quran di MTs Al-Muhsin II adalah mata pelajaran lokal yang diwajibkan bagi setiap peserta didik. Kendati demikian bukan berarti dalam pelaksanaannya tidak mengalami kendala, bahkan menjadi pekerjaan besar bagi civitas program Tahfidz Al-Quran di MTs Al-Muhsin II ini, pasalnya sebagian besar peserta didik sendiri masih banyak yang belum bisa baca tulis Al-Quran, hal ini disampaikan oleh mereka bahwa mayoritas peserta didik yang berasal dari Sekolah Dasar (SD) memiliki kelemahan tersebut, sangat berbanding terbalik dengan peserta didik lulusan Madrasah Ibtidaiyyah (MI). Hal inilah yang menjadi pekerjaan besar bagi civitas program Tahfidz di MTs Al-Muhsin II tersebut.

Selain itu dalam proses belajar mengajar dibutuhkan beberapa hal yang mendukung pengajarannya, baik dari segi fasilitas berupa fisik ataupun nonfisik, dalam hal ini sangatlah diperlukan. Ketika dua hal ini telah tercukupi maka otomatis minat peserta didik pun akan meningkat dan terus terpupuk. Sedangkan apabila terdapat kepincangan atas dua hal tersebut sudah bisa dipastikan pengajaran akan mengalami kendala yang berarti. 
Beberapa fasilitas yang dapat mendukung pembelajaran dalam program Tahfidzul Quran dari segi fisik adalah papan tulis, spidol, penghapus, Al-Quran sebanyak jumlah peserta didik, media LCD serta audio visual, ruangan belajar yang bersih dan nyaman, dan buku panduan belajar Al-Quran metodik (sesuai dengan kebijakan lembaga). Sedangkan fasilitas pendukung nonfisiknya adalah guru yang memiliki kompetensi AI-Quran yang baik, memiliki keterampilan seni dan kreativitas guru dalam mengajar, kemudian RPP yang tersusun rapi, target belajar yang jelas, suasana kelas yang kondusif, serta dukungan penuh dari semua pihak yaitu guru, sekolah, maupun orang tua peserta didik. Dan jika ditabelkan, maka fasilitas tersebut dapat dilihat dalam table berikut.

Tabel 1. Fasilitas Pendukung Pembelajaran Tahfidz Quran di MTs Al-Muhsin II

Fasilitas Pendukung fisik

$>$ Papan tulis, spidol dan penghapus

$>$ Al-Quran dan buku panduan Yanbuul Quran Kudus

> Buku IQRO dan Juz 'Amma

$>$ Layar LCD

$>$ Audio-Visual

$>$ Kelas yang bersih dan kondusif

$>$ Poster-poster Qurani

$>$ Jadwal setoran dan prestasi hafalan peserta didik

$>$ Lembar penilaian perkembangan Tahfidz AlQuran peserta didik

\section{Fasilitas Pendukung Nonfisik}

Guru atau pengampu yang kompeten (memiliki sanad keilmuan Al-Quran yang muttashil sampai pada Nabi Muhammad SAW)

> Kemampuan pedagogik guru

$>$ Suasana kelas yang Qurani

> Dorongan dan motivasi dari guru dan orang tua peserta didik

Kedekatan guru dan peserta didik

$>$ Pembelajaran yang tidak menjenuhkan

$>$ Penerapan kebiasaan disiplin dalam belajar

$>$ Pembiasaan membaca Al-Quran secara bersama-sama

Sumber: Munastiwi, 2020

MTs Al-Muhsin II dikenal sebagai Madrasah Islam berbasis pondok pesantren yang terletak di Bantul tersebut tentu tidak akan pernah kehabisan referensi apabila membutuhkan guru pengampu program tahfidz ini. Beberapa pengampu tahfidz Al-Quran adalah mayoritas lulusan pondok pesantren yang tentunya memiliki kredibelitas dalam pengetahuan Al-Quran. Tentu hal ini menjadi nilai tambah tersendiri mengingat ada syarat mutlak yang harus terpenuhi yaitu guru yang memiliki sanad ajar yang muttashil (nyambung) sampai Rasulullah SAW. Perlu diketahui juga bahwa di MTs Al-Muhsin II dari segi metodik dalam pengajaran Al-Quran adalah menggunakan Yanbu Al-Quran Pondok Pesantren KH. Arwani Kudus sehingga bisa dipahami bahwa sanadnya menyambung melalui jalur KH. Arwani Kudus tersebut.

Dalam hal kompetensi keilmuan tentu tidak diragukan lagi, mangingat mayoritas guru merupakan lulusan pesantren, namun akan berbeda lagi apabila dilihat dari sisi pedagogik. Beberapa guru mungkin memiliki latar belakang yang berbeda. Jika guru lulusan pesantren murni maka dalam hal pedagogik akan 
mengalami kesulitan jika guru terkait mencoba menerapkan metode ajar yang biasa di pesantren secara total tanpa mengelaborasi kondisi peserta didiknya. Namun akan menjadi kelebihan tersendiri apabila guru terkait selain memang lulusan pesantren ia juga dibekali latar pendidikan sarjana dengan background pendidikan. Hal ini bukan berarti metode ajar yang ada di pesantren merupakan metode yang lemah namun karena kondisi peserta didik di madrasah berbeda dengan santri di pondok pesantren, maka metode dan strateginya pun harus disesuaikan.

Minat memiliki makna dengan kesukaan dan keinginan anak terhadap suatu hal maka seseorang akan dikatakan memiliki minat apabila ia memiliki dorongan dari dalam dirinya maupun dari luar dirinya untuk melakukan sesuatu tersebut. Minat biasanya mendominasi kegiatan seseorang dalam kehidupan sehari-harinya. Senada dengan Crow menjelaskan bahwa minat merupakan kekuatan pendorong yang menyebabkan seseorang memiliki simpati terhadap orang lain atau objek lain. Sementara itu Hurlock menjelaskan bahwa minat adalah sumber motivasi untuk melakukan sesuatu yang dikehendakinya (Hikmawati \& Munastiwi, 2018).

Apabila berbicara minat maka sudah pasti akan berkaitan dengan kreatifitas peserta didik pada sesuatu hal yang relevan dengannya. Kreatifitas adalah bagian dari aktualisasi diri seseorang (seperti pandangan Abraham Maslow) maka apabila seorang anak didik mengekspresikan segala minat, bakatnya niscaya akan bisa mengekspresikan kreativitasnya (Munandar, 2014, p. 18). Sedangkan Rogers menjelaskan bahwa kreatifitas adalah kecenderungan untuk mengaktualisasikan diri, mewujudkan potensi, dorongan untuk berkembang, dan menjadi matang, kecenderungan untuk mengekspresikan dan mengaktualisasikan dan mengaktifkan semua organisme dalam dirinya secara total (Munandar, 2014, p. 18).

Seperti halnya dalam program Tahfidz Al-Quran pada umumnya, di sekolah pun sangat berpengaruh antara kondisi diri peserta didik yang memiliki minat di awal dan peserta didik yang kurang begitu menaruh perhatian di awal program. Apabila seorang anak didik memiliki minat dan perhatian lebih terhadap program tahfidz Quran ini maka dalam proses pengajarannya pun akan membuat peserta didik tersebut memiliki ketertarikan terhadap hal lain yang berkaitan dengan Al-Quran seperti saritilawah Al-Quran, tartil Al-Quran, maupun tahfidzul Quran itu sendiri. Maka dalam kondisi tersebutlah dilakukan berbagai model pembelajaran yang menarik agar peserta didik secara keseluruhan menaruh perhatian terhadap pembelajaran Tahfidz Al-Quran di Madrasah.

Terdapat stimulasi untuk mendukung minat peserta didik. Stimulasi adalah merupakan usaha yang dilakukan oleh guru guna memupuk semangat peserta didik, agar dapat mengikuti program Tahfidz dengan baik. Guru yang kreatif dalam hal ini tentu sangat dibutuhkan agar proses pengajaran tidak membosankan dan menjenuhkan anak didik. Ikhtiar ini guru bisa menggunakan beberapa cara, diantaranya adalah pertama dengan strategi dan trik pembelajaran yang menyenangkan, seperti metode pengalihan dalam menghafal Al-Quran yakni peserta didik diajak untuk menghafalkan Al-Quran dengan cara berdiri, duduk, lari-lari, atau dengan posisi lainnya selama itu memungkinkan dilakukan. Hal ini dilakukan dengan maksud agar peserta didik tidak merasakan beban menghafalkan dalam dirinya. Cara ini termasuk cara yang banyak 
dipraktekan di sekolah. Cara kedua adalah guru menyetel audio-visual bacaanbacaan Al-Quran yang merdu dari imam-imam yang masyhur dalam bacaan AlQuran, hal ini akan mensugesti diri peserta didik sehingga termotivasi untuk meneladaninya. Cara ketiga adalah guru membuat permainan namun masih seputar pengajaran Al-Quran seperti sambung ayat atau tebak surat. Dan bagi peserta didik yang menang akan mendapatkan rewards dari guru. Dan masih banyak trik-trik kecil lain yang dilakukan pengajar secara spontan untuk menstimulasi peserta didik seperti halnya guru mata pelajaran pada umumnya seperti ice breaking di tengah pembelajaran, di awal pembelajaran dan akhir pembelajaran untuk membangun kedekatan antara guru dan peserta didik.

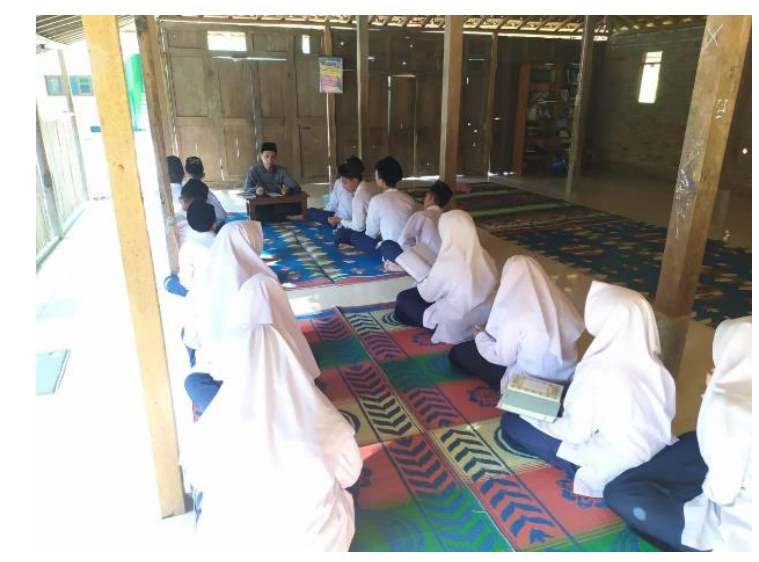

\section{Gambar 1. Pengajaran Program Tahfidz di MTs Al-Muhsin II}

Sumber: Munastiwi, 2020

Satu cara lain untuk menstimulasi minat peserta didik dalam tilawatil Quran adalah dengan cara membuat halaqah ketika pengajaran berlangsung, maksudnya adalah dengan cara membuat kelompok kecil atau halaqah tersebut. Caranya adalah guru menetapkan jumlah surat atau ayat yang akan dihafalkan oleh santri halaqah. Kemudian guru membacakan ayat atau surat yang akan dihafalkan kepada peserta didik, dan santri selanjutnya membaca di depan gurunya. Secara bersamaan maupun bergantian. Selanjutnya peserta didik dipersilahkan untuk menghafal masing-masing sesuai dengan kemampuannya yang telah dikaruniakan Allah SWT kepadanya, dan tentu di bawah bimbingan dan pengawasan guru. Salah satu upaya agar berjalannya pembelajaran agar kondusif yaitu dengan menerapkan pendisiplinan dalam halaqah tersebut. Penegakan ini dilakukan untuk mencegah malasnya peserta didik selama proses pembelajaran. Sehingga mereka menjadi taat dan rajin.

\section{SIMPULAN}

Dari beberapa pembahasan terkait program pengajaran dalam program tahfidz Al-Quran membutuhkan beberapa elemen penting yang harus dipenuhi agar dapat membuat anak didik memiliki minat terhadapnya di antaranya adalah tahsinul Quran, metode yang digunakan, strategi yang digunakan, kasih sayang guru dan kesabaran dalam mengajarkan Al-Quran, peran guru dalam mentoring pembelajaran Al-Quran, kreativitas guru mengemas pengajaran secara menarik dan tidak membosankan (stagnan), selain itu juga diperlukan pendisiplinan, dan 
terakhir yag paling berpengaruh adalah faktor pendukung baik yang berupa fisik maupun nonfisik.

Fasilitas secara umum MTs Al-Muhsin II telah memiliki sebagian besar fasilitas pendukung dalam pelaksanaannya namun tetap saja kendala terbesar adalah kemampuan mayoritas yang belum memadai yang dimiliki peserta didik akan menghambat kelancaran program Tahfidz AI-Quran di MTs Al-Muhsin II ini. Maka salah satu cara agar capaian pembelajaran program Tahfidz di MTs AlMuhsin II sebagai standar kenaikan kelas atau kelulusan akan disesuaikan dengan kemampuan peserta didik yang ada mengingat program ini adalah bukan standar dalam skala nasional.

\section{REFERENSI}

Che Noh, M. A., \& Ahmad, R. (2009). Persepsi Pelajar Terhadap Amalan Pengajaran Tilawah Al-Quran. Jurnal Pendidikan Malaysia, 34(1), 93-109. https://ejournal.ukm.my/jpend/article/view/13434/4258

Creswell, J. W. (2014). Research Design: Pendekatan Kualitatif, Kuantitatif dan Mixed. Pustaka Pelajar.

Hasyimi, M. A. (1994). Membentuk Kepribadian Muslimah Ideal Menurut AlQuran dan Sunnah. Al-I'tishom.

Hikmawati, N., \& Munastiwi, E. (2018). Manajemen Perpustakaan Efektif dalam Menumbuhkan Minat Baca Anak. Golden Age: Jurnal Ilmiah Tumbuh Kembang Anak Usia Dini, 3(3), 165-178. http://ejournal.uinsuka.ac.id/tarbiyah/index.php/goldenage/article/view/2347

Khoiruddin, H., \& Kustiani, A. W. (2020). Manajemen Pembelajaran Tahsin AlQuran Berbasis Metode Tilawati. Jurnal Isema : Islamic Educational Management, 5(1), 55-68. https://doi.org/10.15575/isema.v5i1.5546

Muhlisin, A. (2017). Peran Guru Dalam Upaya Meningkatkan Kualitas Baca Tulis Al-Quran di TPQ Miftahul Ulum Nglele Sumobito Jombang. Al Murabbi, 2(2), 275-290.

https://jurnal.yudharta.ac.id/v2/index.php/pai/article/view/607

Munandar, U. (2014). Pengembangan Kreativitas Anak Berbakat. Rineka Cipta.

Prasetiawati, E. (2019). Pengembangan Bahan Ajar Tahsinul Qiro ' ah Berbasis An-Nahdliyah Untuk Meningkatkan Ketrampilan Membaca Al- Qur' an. Tadris: Jurnal Pendidikan Islam, 14(2), 131-146. https://doi.org/10.19105/tjpi.v14i2.2389

Putra, S. R. (2016). Metode Pengajaran Rasulullah SAW (Segudang Strategi Belajar Mengajar Berdasar Sifat-Sifat Rasulullah). Diva Press.

Rohmatillah, S., \& Shaleh, M. (2018). Manajemen Kurikulum Program Tahfidz Al-Qur'an di Pondok Pesantren Salafiyah Syafi'iyah Al-Azhar Mojosari Situbondo. Jurnal Pendidikan Islam Indonesia. https://doi.org/10.35316/jpii.v3i1.91

Shihab, M. Q. (2006). Membumikan Al-Qur'an, Fungsi dan Peran Wahyu dalam Masyarakat. Mizan Media Utama.

Sitna, S., Abdurrahman, M., \& Nufus, H. (2019). Motivasi Orang Tua Menyekolahkan Anaknya di Pesantren Sebagai Sarana Pembinaan Akhlak (Studi Kasus Pada Pondok Pesantren Shuffah Hizbullah Dusun Oli Desa Hitu Kecamatan Leihitu Kabupaten Maluku Tengah). Kuttab: Jurnal IImiah Mahasiswa, 1(1), 1. https://doi.org/10.33477/kjim.v1i1.880 
F. S. Anwar, E. Munastiwi

Supriatna, D. (2018). Motivasi Orang Tua Memilih Pondok Pesantren untuk Anaknya. Intizar, 24(1), 1-18. https://doi.org/10.19109/intizar.v24i1.1951

Taher, S. M., \& Munastiwi, E. (2019). Peran Guru Dalam Mengembangkan Kreativitas Anak Usia Dini Di TK Islam Terpadu Salsabila Al-Muthi'in Yogyakarta. Golden Age: Jurnal IImiah Tumbuh Kembang Anak Usia Dini, 4(2), 35-50. https://doi.org/10.14421/jga.2019.42-04 